\title{
Pidana Mati Terhadap Kejahatan Narkotika Ditinjau Dari Pasal 28I Ayat (1) UUD NRI 1945
}

\author{
Roby Anugrah*, Raja Desril dan Hari Sutra Disemadi \\ Fakultas Hukum Universitas Muhammadiyah Riau \\ *robbyanugrah@umri.ac.id
}

Published: 30/07/2020

How To Cite:

Anugrah, R., Desril, R., Disemadi. (2020). Pidana Mati Terhadap Kejahatan Narkotika Ditinjau Dari Pasal 28I Ayat (1) UUD NRI 1945. KERTHA WICA KSANA: Sarana Komunikasi Dosen dan Mahasiswa. 14 (2). Pp 110 - 117. https://doi.org/10.22225/kw.14.2.1922.110-117

\begin{abstract}
Abstrak
Perdebatan mengenai pidana mati dari zaman klasik hingga zaman modern masih menjadi perdebatan yang belum menemukan titik dialogisnya. Dari zaman Beccaria yang menyatakan bahwa pidana mati tidak efektif dalam menanggulangi kejahatan, pembunuhan banyak terjadi dan masih akan terus terjadi hingga dewasa ini pihak pro dan kontra pidana mati masih mempertahankan argumennya masing-masing. Dalam menjawab permasalahan mengenai pro-kontra pidana mati terhadap palaku kejahatan narkotika, maka penelitian ini menggunakan metode analisis kualitatif dengan jenis penlitian hukum normatif. Data yang digunakan pada penelitian hukum normatif tentunya adalah data sekunder yang diperoleh melalui studi kepustakaan. Di Indonesia perdebatan mengenai pidana mati terhadap pelaku kejahatan Narkotika kembali mencuat ke publik ketika ketentuan ancaman pidana mati dalam UU Narkotika diajukan uji materil atau judicial review kepada Mahkamah Konstitusi yang dianggap bertentangan dengan hak asasi manusia paling dasar yakni hak untuk hidup yang dijamin oleh UUD 1945. Padahal apabila ditelaah pidana mati terhadap kejahatan narkotika dan terhadap kejahatan lain pada umumnya sepanjang diatur secara tegas dalam peraturan perundang-undangan tidaklah bertentangan dengan hak untuk hidup yang dimiliki manusia dari sejak lahir.
\end{abstract}

Kata Kunci: Hak hidup, kejahatan narkotika, pidana mati

\begin{abstract}
The debate about capital punishment from classical to modern times is still a debate that has not found a dialogue point. From the Beccaria era which stated that capital punishment was not effective in tackling crime, many killings occurred and will continue to occur until today the pros and cons of capital punishment still maintain their respective arguments. In answering the problems regarding the pros and cons of capital punishment against narcotics crime, this study uses a qualitative analysis method with a type of normative legal research. The data used in normative legal research is, of course, secondary data obtained through library research. In Indonesia, the debate about capital punishment against narcotics criminals reappears to the public when the provisions of the threat of capital punishment in the Narcotics Law are submitted to a judicial review or judicial review to the Constitutional Court which is considered to conflict with the most basic human rights namely the right to life guaranteed by the 1945 Constitution. Whereas if the death penalty is investigated for narcotics crimes and other crimes in general as long as it is firmly regulated in statutory regulations it does not contradict the right to life that humans have from birth.
\end{abstract}

\section{Keywords: Right to life, narcotics crimes, death penalty}

\section{PENDAHULUAN}

Indonesia sebagai negara yang terdiri dari jajaran pulau-pulau yang membentang dari sabang hingga merauke menjadikan bangsa Indonesia sebagai bangsa bahari terbesar di dunia. Dengan letaknya yang strategis, sebagai titik singgng dalam persilangan perdagangan dan budaya antar bangsa, menjadikan Indonesia memiliki keuntungan dalam hal perdagangan dengan negara dan bangsa lainnya (Gukguk \& Jaya, 2019; Reksodiputro, 2012). Letak geografis Indonesia yang strategis dalam jalur perdagangan 
tersebut dimanfaatkan oleh orang-orang yang tidak bertanggungjawab untuk melakukan perdagangan secara ilegal. Perdagangan secara ilegal tersebut didominasi oleh perdagangan gelap Narkotika. Pada kenyataannya, kejahatan narkotika memang telah menjadi sebuah kejahatan transnasional yang dilakukan oleh kelompok kejahatan terorganisir atau organized crime (Busnarma, 2019; Gukguk \& Jaya, 2019).

Kejahatan narkotika merupakan kejahatan transnasional dalam artian bahwa semua negara di dunia mengutuk dan melarang segala hal yang terkait dengan perdagangan gelap narkotika tersebut mengingat bahwa narkotika membei efek atau dampak yang buruk bagi setiap bangsa terutama bagi generasi penerus bangsa (Istighfar, Jaya, \& Pujiyono, 2017). Selain daripada itu maksud dari kejahatan narkotika sebagai kejahatan transnasional adalah bahwa kejahatan narkotika telah terjadi di semua negara dan kejahatan narkotika tersebut berpotensi besar terjadi dalam lintas negara (Heriyono, 2020; Reksodiputro, 2012).

Indonesia sebagai bagian dari masyarakat dunia turut menyadari efek buruk dari narkotika dan psikotoprika bagi kehidupan dan kelangsungan suatu bangsa maka dari itu Indoanesia secara nasional menyatakan perang terhadap kejahatan narkotika psikotropika. Wujud nyata dari bangsa Indonesia dalam memerangi kejahatan narkotika dan psikotropika adalah dengan disahkannya UU No. 5 Tahun 1997 Tentang Psikotoprika dan Undang-Undang Nomor 35 Tahun 2009 tentang Narkotika (UU Narkotika). Melalui peraturan perundangundangan tersebut Indonesia secara tegas mengecam segala tindakan dan perbuatan yang bersangkut paut dengan kejahatan narkotika. Berdasarkan UU Psikotropika an UU Narkotika pada beberapa pasalnya diatur mengenai sanksi pidana mati bagi siapa saja yang melanggar UU narkotika tersebut.

Penggunaan pidana mati sebagai alat untuk menanggulangi kejahatan juga tidak terlepas dari pro dan kontra, karena masalah pidana mati di Indonesia sampai saat ini masih merupakan pembicaraan yang dapat menimbulkan problem (Jainah \& Handayani, 2019). Hal ini disebabkan karena persepsi tentang pidana mati sangat dipengaruhi oleh latar belakanag budaya dan pandangan hidup bangsa. Masalah pidana mati bertalian erat dengan struktur masyarakat, kondisi politik, dan nilai-nilai budaya yang ada dalam masyarakat itu (Sahetapy, 1982).

Menurut pihak pro pidana mati menyatakan bahwa pidana mati dapat dipergunakan sebagai alat radikal untuk mencegah tindakan-tindakan yang di luar batas-batas perikemanusiaan demi terlaksananya cita-cita masyarakat Indoneisa yang adil dan makmur (Istighfar et al., 2017). Namun demikian, menurut pihak kontra pidana mati menyatakan bahwa pidana mati bertentangan dengan perikemanusiaan dan hak asasi manusia terutama hak untuk hidup sebagaimana yang diatur pada UUD 1945 Pasal 28I ayat (1) yang menyatakan bahwa "hak untuk hidup..... adalah hak asasi manusia yang tidak dapat dikurangi dalam keadaan apa pun" ketentuan ini telah menegasikan keberadaan hukuman mati dalam sistem hukum Indonesia. Lahirnya Pasal 28I ayat (1) UUD 1945 tidak bisa tidak berakibat pada inkonstitusionalitas hukuman mati (Lubis, 2009).

Menurut pihak kontra pidana mati konsekuensi logis dari pola pikir diatas adalah bahwa semua produk peraturan perundangundangan yang berada dibawah UUD 1945 haruslah mengalami perubahan dalam artian pasal -pasal mengenai pidana mati harus dihilangkan (Sitanggang \& Fakhriah, 2019), terutama berkaitan dengan pasal-pasal yang berkaitan dengan ancaman pidana mati terhadap kejahatan Narkotika yang diatur dalam UU Narkotika karena hukuman mati dinilai sebagai sebuah pelanggaran hak asasi manusia yang paling mendasar yaitu hak untuk hidup sebagaimana disebutkan dalam pasal 28A UUD 1945, bahwa setiap orang berhak untuk hidup serta berhak mempertahankan hidup dan kehidupannya (Arief, 2019; Istighfar et al., 2017).

Terhadap pasal-pasal yang mengatur pidana mati dalam kejahatan Narkotika tersebut diajukanlah judicial review ke Mahkamah Konstitusi guna untuk menghapus ancaman pidana mati terhadap kejahatan narkotika karna pidana mati bertentangan dengan Pasal 28I ayat (1) UUD 1945.

Penelitan mengenai pidana mati dari dulu hingga kini masih relevan untuk dilakukannya pengkajian dikarenakan bahwa norma-norma hukum itu berkembang begitu juga dengan masyarakat sebagai subjek dari hukum itu sendiri juga mengalami perubahan dan perkembangan. Penelitian-penelitian terkait pidana mati yang telah ada sebelumnya dewasa ini berkisar mengenai kebijakan formulasi pidana mati terhadap pelaku tindak pidana korupsi di 
Indonesia (Batubara, 2014), penelitian lain berfokus pada eksistensi pidana mati dalam hukum pidana (Eleanora, 2012), dan penelitian lainnya seperti efektifitas pidana mati bagi pelaku kejahatan narkotika di Indonesia (Istighfar et al., 2017).

Penelitian-penelitian yang telah ada terdahulu lebih memfokuskan pengkajiannya kepada eksistensi pidana mati terhadap kejahatan korupsi, eksistensi pidana mati itu sendiri dalam bingkai hukum pidana serta jalan tengah mengenai prokontra pidana mati. Penelitian-penelitian terdahulu belum memfokuskan pengkajiannya kepada analisis pidana mati jika dihadapkan dengan UUD 1945 dan mendasarkan penelitiannya kepada putusan Mahkamah Konstitusi yang melakukan Judicial Review terhadap pasal-pasal dalam UU Narkotika yang mengatur pidana mati. Berdasarkan paparan di atas, maka permasalahan yang ingin dikaji pada penelitian kali ini adalah: 1). Bagaimana Pengaturan Ancaman Pidana Mati Terhadap Kejahatan Narkotika Di Indonesia?; dan 2). Bagaimana Putusan Mahkamah Konstitusi Mengenai Pidana Mati Di Indonesia Ditinjau Dari Pasal 28I Ayat (1) UUD 1945?.

\section{METODE}

Penelitian ini merupakan penelitian hukum normatif, karena sumber data yang digunakan adalah data sekunder berupa bahan hukum primer, bahan hukum sekunder maupun bahan hukum tersier. Bahan hukum primer berupa bahan hukum yang memiliki kekuatan mengikat seperti Kitab Undang-undang Hukum Pidana, UU Narkotika, Putusan Mahkamah Konstitusi No 2-3/ PUU-V/2007. Bahan hukum sekunder berupa pendapat ahli dan bahan hukum tersier berupa tulisan-tulisan jurnal terdahulu. Data sekuder diperoleh melalui teknik pengumpulan data studi kepustakaan yang kemudian di pilah dan dianalisis menggunakan teknik analisis kualitatif untuk memperoleh kesimpulan yang tepat.

\section{III.HASIL DAN PEMBAHASAN}

\section{Ancaman Pidana Mati Bagi Pelaku Kejahatan Narkotika Di Indonesia}

Hukum pidana dapat didefiniskan sebagai: aturan hukum, yang mengikatkan kepada suatu perbuatan yang memenuhi syarat-syarat tertentu suatu akibat yang berupa pidana (Rofiq, Disemadi, \& Jaya, 2019; Sudarto, 2009). Hukum pidana dapat dibedakan dan diberikan arti menjadi hukum pidana materiil dan hukum pidana formil. Hukum pidana materiil yang menunjuk pada perbuatan-perbuatan yang dapat dipidana, aturan-aturan yang memuat syaratsyarat untuk dapat menjatuhkan pidana dan ketentuan mengenai sanksi pidana itu sendiri (Anugrah, 2019). Adapun hukum pidana formil mengatur bagaimana negara dengan perantaraan alat-alat perlengkapan-nya melaksanakan haknya untuk mengenakan pidana atau dalam kata lain disebutkan sebagai hukum yang mengatur cara hukum pidana materill dapat dilaksanakan (Lasmadi, Sari, \& Disemadi, 2020).

Hukum pidana materiil di Indonesia dibagi menjadi dua (2) bagian, yakni hukum pidana umum yang merujuk kepada Kitab UndangUndang Hukum Pidana (KUHP/WvS) dan hukum pidana khusus yakni segala peraturan perundangundangan hukum pidana diluar KUHP (WvS). KUHP (WvS) merupakan induk dari segala peraturan perundang-undangan hukum pidana di Indonesia, dalam artian bahwa ketentuan umum buku I KUHP (WvS) mengikat bagi setiap perundang-undangan pidana diluar KUHP (WvS) tersebut. Menurut KUHP (WvS) jenis-jenis pidana yang diatur dalam Pasal 10 KUHP adalah sebagai berikut :

Pidana terditi atas:

Pidana Pokok: Pidana mati, Pidana penjara, Kurungan, Denda

Pidana tambahan: Pencabutan hak-hak tertentu, Perampasan barang-barang tertentu, Pengumuman putusan hakim.

Berdasarkan Pasal 10 KUHP diatas pidana mati mendapat legitimasi untuk berlaku secara sah dan konstitusional di Indonesia. Pidana mati ditempatkan sebagai pidana pokok dan berada pada puncak hierarki jenis pidana karna tidak ada lagi ancaman pidana yang melebihi pidana mati. Berdasarkan bahwa ketentuan mengenai jenisjenis pidana yang diatur dalam Pasal 10 KUHP tersebut adalah dimuat pada Buku I KUHP yang mana Buku I KUHP tentang ketentuan umum tersebut mengikat bagi seluruh perundangundangan pidana diluar KUHP maka pengaturan ancaman pidana mati terhadap pelaku kejahatan Narkotika adalah tidak bertentangan dengan ketentuan umum dalam KUHP.

Hukum pidana khusus sebagaimana telah disebutkan diatas adalah peraturan perundangundangan hukum pidana diluar KUHP yang mana pada beberapa perundang-undangan tersebut juga diaturnya mengenai ancaman pidana mati bagi 
pihak yang melanggar perundang-undangan tersebut. Perundang-undangan hukum pidana diluar KUHP yang memuat sanksi pidana mati antara lain mengenai kejahatan Narkotika di Indonesia adalah merujuk dengan merujuk kepada UU No. 5 Tahun 1997 Tentang Psikotropika, UU No. 22 Tahun 1997 Tentang Narkotika jo UU No. 35 Tahun 2009 Tentang Narkotika.

Menurut UU No. 5 Tahun 1997 Tentang Psikotropika tindak pidana yang diancam dengan pidana mati adalah tindak pidana yang tertuang dalam Pasal 59 ayat (2) yaitu tindak pidana sebagaimana yang diatur dalam pasal 59 ayat (1) yang dilakukan secara terorganisasi. Adapun tindak pidana sebagaimana yang dimaksud dalam Pasal 59 ayat (1) UU No.5 tahun 1997 meliputi:

Menggunakan psikotropika golongan I selain dimaksud dalam Pasal 4 ayat (2);

Memproduksi dan/atau menggunakan dalam proses produksi psikotropika golongan I sebagaimana dimaksud dalam Pasal 6; atau

Mengedarkan psikotropika golongan I tidak memenuhi ke-tentuan sebagaimana dimaksud dalam Pasal 12 ayat (3); atau

Mengimpor psikotropika golongan I selain untuk kepentingan ilmu pengetahuan; atau

Secara tanpa hak memiliki, menyimpan dan/ atau membawa psikotropika golongan I.dipidana dengan pidana penjara paling singkat 4 (empat) tahun, paling lama 15 (lima belas) tahun dan pidana denda paling sedikit Rp. 150.000.000,00 (seratus lima puluh juta rupiah), dan paling banyak Rp.750.000.000,00 (tujuh ratus lima puluh juta rupiah).

Menurut UU No. 22 Tahun 1997 Tentang Narkotika ancaman pidana mati termuat dalam Pasal 80 ayat (1) huruf a yang berbunyi: "Barangsiapa tanpa hak dan melawan hukum: memproduksi, mengolah, mengekstaksi, mengkonvensi, merakit,atau menyediakan narkotika Golongan I, dipidana dengan pidana mati atau pidana penjara seumur hidup, atau pidana penjara paling lama 20 (dua puluh) tahun dan denda paling banyak Rp. 1.000.000.000,00 (satu milyar rupiah)".

Selanjutnya Pasal 80 ayat (3) huruf a dinyatakan "Apabila tindak pidana sebagaimana dimaksud dalam : a. Ayat (1) huruf a dilakukan secara terorganisasi, dipidana dengan pidana mati atau pidana penjara seumur hidup atau pidana penjara paling singkat 5 (lima) tahun dan paling lama 20 (dua puluh) tahun dan denda paling sedikit Rp. 500.000 .000 (lima ratus juta rupiah) dan paling banyak Rp. 5.000.000.000 (lima milyar rupiah)".

Sementara demikian dalam UU No.35 Tahun 2009 tentang Narkotika, tindak pidana yang diancam dengan pidana mati dalam Undangundang ini terdapat pada pasal-pasal berikut:

Pasal 113 ayat (2) - perbuatan memproduksi, mengimpor, atau menyalurkan Narkotika golongan I dalam bentuk tanaman beratnya $1 \mathrm{~kg}$ atau 5 batang pohon atau dalam bentuk bukan tanaman beratnya melebihi 5 gram;

Pasal 114 ayat (2) - perbuatan menawarkan untuk dijual, menjual, membeli, menjadi perantara dalam jual beli, menukar, menyerahkan atau menerima Narkotika golongan I dalam bentuk tanaman beratnya $1 \mathrm{~kg}$ atau 5 batang pohon atau dalam bentuk bukan tanaman beratnya melebihi 5 gram;

Pasal 116 ayat (2) - penggunaan narkotika terhadap orang lain atau pemberian Narkotika golongan I untuk digunakan orang lain, mengakibatkan orang lain mati atau cacat permanen;

Pasal 118 ayat (2) - memproduksi, mengimpor, mengekspor, atau menyalurkan Narkotika golongan II beratnya melebihi 5 gram;

Pasal 119 ayat (2) - menawarkan untuk dijual, menjual, membeli, menerima, menjadi perantara dalam hal jual beli, menukar, menyerahkan Narkotika golongan II beratnya melebihi 5 gram;

Pasal 121 ayat (2) - penggunaan narkotika untuk orang lain atau pemberian Narkotika golongan II untuk digunakan orang lain, mengakibatkan orang lain mati atau cacat permanen;

Pasal 133 - menyuruh, memberi, atau menjanjikan sesuatu, memberikan kesempatan, menganjurkan, memberi kemudahan, memaksa dengan ancaman, memaksa dengan kekerasan, melakukan tipu muslihat, atau membujuk anak yang belum cukup umur untuk melakukan tindak pidana dalam Pasal 111 sampai dengan Pasal 126 dan Pasal 129.

Berdasarkan Pasal-Pasal yang telah disebutkan diatas tersebut dapat dilihat bahwa pembentuk Undang-Undang berusaha melindungi setiap Individu bangsa Indonesia dari penyalahgunaan 
Psikotropika dan Narkotika (Arief, 2019; Busnarma, 2019), terkhusus narkotika golongan I yang merupakan obat-obatan dengan daya adiktif tinggi dan memiliki potensi yang besar atau cukup tinggi untuk menyebabkan kecanduan. Narkotika golongan I ini sangat berbahaya jika disalahgunakan dapat merusak organ tubuh hingga menyebabkan kematian.

Tingginya bahaya efek samping dari kecanduan narkotika golongan I ini sehingga wajar menurut penulis pembentuk UndangUndang merumuskan ancaman pidana mati. Dengan dirumuskannya ancaman pidana mati dalam tiap-tiap Pasal yang disebutkan diatas maka dapat diketahui bahwa pemerintah Indonesia serius dalam usaha perang melawan Narkotika guna melindungi setiap individu bangsa Indonesia dari kerusakan dan bahaya penyalahgunaan narkotika (Batubara, 2014; Istighfar et al., 2017).

Putusan Mahkamah Konstitusi Mengenai Pidana Mati Di Indonesia Ditinjau Dari Pasal $28 I$ Ayat (1) UUD 1945

Mahkamah Konstitusi sebagai lembaga peradilan di Indonesia memiliki kewenangan dalam hal judicial review atau sebagai penguji materiil undang-undang terhadap UUD. Judicial review atau contitutional review di dalamnya terdapat dua (2) cakupan tugas pokok yang meliputi: pertama, menjamin berfungsinya sistem demokrasi dalam hubungan perimbangan peran antara kekuasaan legislatif, eksekutif, dan yudikatif supaya tidak terjadi pemusatan kekuasaan oleh satu cabang kekuasaan terhadap cabang kekuasaan laiinya; kedua, melindungi setiap individu warga negara dari penyalahgunaan kekuasaan oleh lembaga negara yang merugikan hak-hak dasar yang dijamin dalam konstitusi (Asshiddiqie, 2006).

Secara konseptual, gagasan pembentukan Mahkamah Konstitusi adalah untuk menyelenggarakan peradilan guna menegakkan hukum dan keadilan. Mengadili tingkat pertama dan terakhir yang putusannya bersifat final dalam hal menguji undang-undang terhadap UndangUndang Dasar 1945, dan kewenangan lain yang dimilikinya (Syahrizal, 2006). Kehadiran Mahkamah Konstitusi melengkapi Mahkamah Agung sebagai lembaga peradilan yang lahir sebelum amandemen UUD 1945 dalam mewujudkan cita-cita bangsa Indonesia sebagai negara hukum. Mahkamah Konstitusi sebagai lembaga kekuasaan kehakiman sudah menjelma dalam sistem hukum ketatanegaraan Indonesia (Darmadi, 2015).

Suatu Pasal atau undang-undang bertentangan dengan UUD 1945 atau tidaknya dapat diajukan uji materiil ke Mahkamah Konstitusi. Berdasarkan Pasal-Pasal dalam UU Psikotropika dan UU Narkotika yang mengatur dapat dijatuhinya pidana mati terhadap pelaku kejahatan narkotika. Meskipun yang diajukan uji materiil atau judicial review ke Mahkamah Konstitusi adalah Pasal-Pasal dalam UU Narkotika yang mengatur mengenai ancaman pidana mati namun tujuan akhir yang hendak dicapai adalah hapusnya pidana mati dalam seluruh ketentuan perundang-undangan Indonesia. Berkaitan dengan hal tersebut Mahkamah Konstitusi telah memberikan pandangan, pendirian dan putusannya dalam Perkara Nomor 2/PUU-V/2007 tersebut.

Dalam memutus perkara Nomor 2/PUUV/2007 tersebut Mahkamah Konstitusi juga melakukan dengar pendapat dari para pakar hukum Indonesia maupun pakar hukum dari negara lain. Berdasarkan berita acara persidangan diketahui juga dalam memberikan pendapatnya secara keilmuan para ahli ini terdapat kontroversi di kalangan para ahli tersebut mengenai bertentangan atau tidaknya pidana mati jika dihadapkan dengan hak untuk hidup sebagaimana yang tertuang dalam Pasal 28A dan Pasal 28J UUD 1945.

Prof. William A. Schabas, OC MRIA seorang guru besar Universitas Nasional Irlandia dan Direktur Pusat Hak Asasi Manusia menerangkan bahwa instrumen-instrumen hukum internasional yang paling mutakhir, yang mengatur tentang kejahatan-kejahatan paling serius (most serious crime) yang menjadi perhatian masyarakat Internasional, yakni genosida, kejahatan terhadap kemanusiaan, dan kejahatan perang, semuanya menolak hukuman mati (Lubis, 2009). Bahkan Statuta Roma tentang Mahkamah Pidana Internasional (Rome Statute of the Internasional Criminal Court) menetapkan hukuman penjara seumur hidup sebagai hukuman maksimal (Heriyono, 2020; Lubis, 2009). Lebih lanjut beliau menyatakan bahwa dalam Pasal 6 Kovenan Internasional tentang Hak-hak Sipil dan Politik cenderung hendak menghapus hukuman mati dapat dilihat pada Ayat (6) dari Pasal 6 tersebut. Adapun menurutnya bahwa konsep pidana mati dapat dijatuhkan terhadap "kejahatan paling serius" Komite Hak-hak Asasi Manusia telah 
memberikan pandangannya bahwa kejahatan drug trafficking yang tidak melibatkan pembunuhan tidak termasuk dalam kategori "kejahatan paling serius".

Prof. Dr. M. Arief Amrullah, S.H., M.Hum seorang pakar hukum pidana Universitas Jember memberikan keterangan dan pendapatnya mengenai pidana mati dalam UU Psikotropika dan Narkotika dihadapkan dengan Pasal 28I dan Pasal 28J UUD 1945 menyatakan bahwa menurutnya yang beliau kutip dari Barda Nawawi Arief salah satu aspek kemanusiaan yang sangat mendasar adalah hak untuk hidup dan hak untuk melangsungkan kehidupannya itu (Lubis, 2009). Karena itu, setiap orang berhak untuk mempertahankan atau membela diri terhadap setiap ancaman atau serangan yang tertuju pada keselamatan jiwanya. Mengingat hak hidup merupakan hak asasi manusia, maka perampasan nyawa oleh Negara berupa penjatuhan pidana mati pada hakikatnya merupakan pelanggaran HAM apabila dilakukan sewenang-wenang, tanpa dasar yang sah menurut hukum yang berlaku. Pandangan tersebut sesuai dengan teori perjanjian masyarakat, dan dalam kaitan ini Van Bemmelen yang mengutip tulisan Rousseau, menyatakan bahwa hukum seluruhnya bersandar pada suatu perjanjian masyarakat, dalam perjanjian itu dinyatakan kehendak bersama. Mengenai tingkah laku yang menurut kehendak bersama tersebut harus dipidana maka hal itu sudah sejak semula harus diuraikan atau ditulis dalam undangundang. Lebih lanjut mengutip dari Muladi menurutnya sikap bangsa Indonesia sudah jelas, bahwa yang kita anut adalah pandangan Partikularistik-relatif, dengan berusaha menemukan titik dialogis di antara empat pandangan HAM atas dasar Pancasila dan UUD 1945, tanpa mengesampingkan substansi dokumen-dokumen internasional tentang HAM. Dalam konteks internasional sebagaimana yang dikemukan oleh Jan Remmelink bahwa beberapa tahun kebelakang muncul kembali gerakangerakan untuk menghapuskan pidana mati di seluruh dunia. Namun demikian menurut Remmelink, bahwa sebenarnya baik protokol ke6 Perjanjian Eropa maupun International Covenant on Civil and Political Rights (ICCPR) tidak melarang pidana mati, tetapi hanya Belanda yang berkenaan dengan Protokol ke-6 tersebut mengaitkan daya berlakunya secara universal. Karena itu, demi untuk melindungi kepentingan nasional yang lebih besar, maka seharusnya ketentuan pidana mati tetap dipertahankan dalam sistem hukum pidana nasional. Dan, itu sesuai dengan Konstitusi (Lubis, 2009).

Pertimbangan Majelis Hakim Konstitusi dalam memberikan Putusan Perkara Nomor 2/PUUV/2007 menyatakan antara lain bahwa dalam sejarah penyusunan Pasal 28I UUD 1945 tatkala merumuskan Bab XA (Hak Asasi Manusia) semangat pembentukan atau merumuskannya adalah menganut pendirian bahwa hak asasi manusia bukan tanpa batas dalam artian hak asasi manusia bukanlah sebebas-bebasnya melainkan dimungkinkan untuk dibatasi sejauh pembatasan itu ditetapkan dengan Undang-undang. Semangat inilah yang melahirkan Pasal 28J UUD 1945 pembatasan tersebut mencakup sejak Pasal 28A sampai dengan Pasal 28I UUD 1945.

Bahwa berdasarkan UU HAM dalam Pasal 9 ayat (1) dimuat ketentuan tentang hak untuk hidup dan dalam Pasal 4 ditentukan bahwa hak untuk hidup termasuk hak asasi manusia yang tidak dapat dikurangi dalam keadaan apapun dan oleh siapapun. Namun, penjelasan Pasal 9 UU HAM menyatakan bahwa hak untuk hidup dapat dibatasi dalam dua hal, yaitu dalam hal aborsi untuk kepentingan hidup ibunya dan dalam hal pidana mati berdasarkan putusan pengadilan.

Selanjutnya menimbang bahwa Indonesia sebagai negara dengan penduduk muslim terbesar di dunia sekaligus juga sebagai anggota Organisasi Konferensi Islam (OKI) secara moral perlu memerhatikan isi Deklarasi Cairo Mengenai Hak-hak Islami yang diselenggarakan OKI yang dalam Pasal 8 huruf a deklarasi tersebut menyatakan "Kehidupan adalah berkah Tuhan dan hak untuk hidup dijamin bagi setiap umat manusia. Adalah tugas dari individu, masyarakat dan negara-negara untuk melindungi hak-hak ini dari setiap pelanggaran apapun, dan dilarang untuk mencabut kehidupan kecuali berdasarkan syariat" Sehingga demikian berdasarkan Pasal 8 huruf a tersebut menurut pandangan negaranegara anggota OKI pencabutan hak untuk hidup yang tidak didasarkan atas hukum yang bersumber dari syariat itulah yang dilarang.

Menimbang bahwa bukti lain yang menunjukkan ketidakmutlakan hak untuk hidup (right to life) dapat diketemukan dalam ICCPR, Pasal 6 ayat (2), Protocol Additional I to the 1949 Conventions and Relating to the Protection of Victims of International Armed Confict Pasal 76 ayat (3), Pasal 77 Ayat (5), Pasal 6 ayat (4), Rome Statute of International Criminal Court Pasal 80. Berdasarkan ketentuan-ketentuan dalam 
berbagai instrumen hukum Internasional di atas menunjukkan bahwa pemberlakuan pidana mati atau penghilangan nyawa dibenarkan sepanjang memenuhi persyaratan atau pembatasanpembatasan yang ditentukan. Persyaratan penjatuhan pidana mati oleh ICCPR hanya dibenarkan terhadap kejahatan serius, sedangkan kualifikasi kejahatan-kejahatan sebagaimana diatur dalam Pasal 80 ayat (1) huruf a, Ayat (2) huruf a, dan Ayat (3) huruf a; Pasal 81 ayat (3) huruf a; Serta Pasal 82 ayat (1) huruf a, Ayat (2) huruf a, dan Ayat (3) huruf a UU Narkotika adalah tergolong ke dalam kelompok kejahatan paling serius baik menurut UU Narkotika maupun menurut ketentuan hukum Internasional yang berlaku saat kejahatan dilakukan.

Mahkamah Konstitusi telah memberikan pandangan, pendirian dan putusannya dalam Perkara Nomor 2/PUU-V/2007 tersebut dengan amar putusan menyatakan ketentuan Pasal 80 ayat (1) huruf a, ayat (2) huruf a; Pasal 81 Ayat (3) huruf a; Pasal 82 Ayat (1) huruf a, Ayat (2) huruf a, dan Ayat (3) huruf a dalam UU Narkotika, sepanjang yang mengenai ancaman pidana mati, tidak bertentangan dengan Pasal 28A dan Pasal 28I ayat (1) UUD 1945, sehingga permohonan pengujian pasal-pasal aquo tidak beralasan dan oleh karena itu permohonan para Pemohon harus ditolak.

Diputuskannya bahwa pidana mati tidak bertentangan dengan UUD 1945 oleh Majelis Hakim Mahkamah Konstitusi ternyata bukanlah sesuatu yang mudah. Faktanya, beberapa Majelis Hakim Mahkamah Konstitusi berbeda pendapat (dissenting oppinion) mengenai hal tersebut. Majelis Hakim Konstitusi H. Harjono, H.M. Laica Marzuki, H.Achmad Roestandi, dan Maruarar Siahaan adalah Majelis Hakim Konstitusi yang berbeda pendapat (dissenting oppinion) mengenai perkara aquo dan menyatakan bahwa seharusnya pidana mati terhadap kejahatan Narkotika adalah bertentangan dengan UUD 1945.

\section{IV.SIMPULAN}

Berdasarkan hasil penelitian yang dilakukan penulis, penulis menarik kesimpulan bahwa ketentuan mengenai ancaman pidana mati khususnya terhadap kejahatan narkotika dan secara umum terhadap kejahatan lainnya yang diancam pidana mati sepanjang diatur secara tegas di dalam perundang-undangan tidaklah bertentangan dengan hak untuk hidup sebagaimana yang diatur dalam Pasal 28I dan 28J
UUD 1945. Mahkamah Konstitusi telah memutuskan bahwa ancaman pidana mati terhadap pelaku kejahatan Narkotika dalam pertimbangannya menyatakan pidana mati tidaklah bertentangan dengan hukum internasional, undang-undang HAM berikut juga dengan UUD 1945 sehingga pidana mati mendapat tempat dan legitimasi dalam hukum Indonesia.

Maka saran atas penelitian kali ini adalah, Mahkamah Konstitusi sebagai lembaga peradilan negara yang dibentuk untuk menegakkan hukum dan keadilan di negara hukum Indonesia memiliki pengaruh yang besar dalam menentukan haluan dan cita-cita hukum bangsa Indonesia. Mahkamah Konstitusi dalam memutuskan perkara uji materill a quo meskipun memiliki perbedaan pendapat dan pandangan (dissenting opinion) diantara Majelis Hakim namun hal tersebut adalah wajar dan menjadi acuan pemerintah untuk bersikap hatihati dalam menjatuhkan pidana mati di Indonesia.

\section{DAFTAR PUSTAKA}

Anugrah, R. (2019). Pemaafan Korban Ditinjau Dari Tujuan Pemidanaan Dalam Pembaharuan Hukum Pidana Di Indonesia. Jurnal Ilmu Hukum, 8(1), 20-35. Retrieved from https:// doi.org/doi.org/10.30652/jih.v8i1.5939

Arief, A. (2019). Problematika Penjatuhan Hukuman Pidana Mati dalam Perspektif Hak Asasi Manusia dan Hukum Pidana. Kosmik Hukum, 19(1), 91-118. https://doi.org/10.30595/ kosmikhukum.v19i1.4086

Asshiddiqie, J. (2006). Hukum Tata Negara dan PilarPilar Demokrasi. Jakarta: Konstitusi Press.

Batubara, R. F. (2014). KEBIJAKAN FORMULASI PIDANA MATI TERHADAP PELAKU TINDAK PIDANA KORUPSI DI INDONESIA. LAW REFORM, 10(1), 74-83. https://doi.org/10.14710/lr.v10i1.12458

Busnarma, T. (2019). PENERAPAN SANKSI PIDANA DENDA TERHADAP PELAKU TINDAK PIDANA PENYALAHGUNAAN DAN PEREDARAN GELAP NARKOTIKA DI PENGADILAN NEGERI PADANG. Soumatera Law Review, 2(1), 172-192. https:// doi.org/10.22216/soumlaw.v2i1.3559

Darmadi, N. S. (2015). Kedudukan Dan Wewenang Mahkamah Konstitusi Dalam Sistem Hukum Ketatanegaraan Indonesia. Jurnal Pembaharuan Hukum, 2(2), 258-269.

Eleanora, F. N. (2012). Eksistensi Pidana Mati Dalam Perspektif Hukum Pidana. Jurnal Ilmiah Widya, 29(318), 10-14.

Gukguk, R. G. R., \& Jaya, N. S. P. (2019). TINDAK PIDANA NARKOTIKA SEBAGAI 
TRANSNASIONAL ORGANIZED CRIME. Jurnal Pembangunan Hukum Indonesia, 1(3), 337-351. https://doi.org/10.14710/jphi.v1i3.337 $-351$

Heriyono. (2020). PELAKSANAAN HUKUMAN MATI DALAM PERSEPEKTIF HAK ASASI MANUSIA. Indonesian Journal of Law and Policy Studies, 1(1), 76-89.

Istighfar, W. A., Jaya, N. S. P., \& Pujiyono. (2017). EFEKTIVITAS PIDANA MATI BAGI PELAKU TINDAK PIDANA NARKOTIKA DALAM PRAKTEK PEMIDANAAN DI INDONESIA DITINJAU DARI SUDUT HAK ASASI MANUSIA. Diponegoro Law Journal, 6 (2), 1-18.

Jainah, Z. O., \& Handayani, I. G. A. K. R. (2019). Death Penalty For Drugs Dealers and Traffickers From The Perspective of Islamic Law. AL-'ADALAH, 15(1), 17-36. https:// doi.org/10.24042/adalah.v15i1.2657

Lasmadi, S., Sari, R. K., \& Disemadi, H. S. (2020). Restorative Justice Approach as an Alternative Companion of the Criminal Justice System in Indonesia. In Proceedings of the International Conference on Law, Economics and Health (ICLEH 2020) (pp. 206-209). Paris, France: Atlantis Press. https://doi.org/10.2991/ aebmr.k.200513.044

Lubis, T. M. (2009). Kontroversi Hukuman Mati Perbedaan Pendapat Hakim Konstitusi. Jakarta: Kompas.

Reksodiputro, M. (2012). SINDIKAT NARKOBA DI INDONESIA DAN ANTISIPASINYA. Legalitas: Jurnal Hukum, 2(1), 12-26. https:// doi.org/doi.org/10.33087/legalitas.v2i1.102

Rofiq, A., Disemadi, H. S., \& Jaya, N. S. P. (2019). Criminal Objectives Integrality in the Indonesian Criminal Justice System. AlRisalah, 19(2), 179-190. https:// doi.org/10.30631/al-risalah.v19i2.458

Sahetapy, J. E. (1982). Suatu Studi Khusus Mengenai Ancaman Pidana Mati Terhadap Pembunuhan Berencana. Jakarta: Rajawali Pers.

Sitanggang, D., \& Fakhriah, E. L. (2019). Disparity of the Waiting Period of the Capital Punishment Execution for Narcotics and Murder Cases in the Perspective of Human Rights. Jurnal Dinamika Hukum, 19(1), 92-111. https:// doi.org/doi.org/10.20884/1.jdh.2019.19.1.1266

Sudarto. (2009). Hukum pidana I. Semarang: Yayasan Sudarto.

Syahrizal, A. (2006). Peradilan Konstitusi, Suatu Studi tentang Adjudikasi Konstitusional Sebagai Mekanisme Penyelesaian Sengketa Normatif. Jakarta: Pradnya Paramita. 